Reflection

http://dx.doi.org/10.1590/0104-07072014000340013

\title{
HUMANIZATION OF HEALTH CARE: A REFLEXIVE THEORETICAL ESSAY BASED ON THE PHILOSOPHY OF EMMANUEL LÉVINAS
}

\author{
Débora Vieira Almeida
}

\begin{abstract}
${ }^{1}$ Ph.D. in Sciences. Post-doctoral student through the Council for the Improvement of Higher Education Personnel (CAPES)s' National Post-Doctoral Program, in the Postgraduate Program in Nursing in Universidade Estadual Paulista. Bauru, São Paulo, Brazil. Email: deboravalmeida@gmail.com
\end{abstract}

\begin{abstract}
Although we don't see this term support in any theory or philosophy what it makes difficult to discuss the humanization in a scientific level. This philosophical essay aims to reflect about the term humanization proposing a concept based in Emmanuel Lévinas philosophy. We propose the "relation I-other as an on the care act" concept. The choice for the levinasian philosophy to fundament the concept is because the health careers finality and complexity that involves the careers knowledge's and makes. In the relation I-another proposed by Lévinas the other appear as an absolute otherness and the I as a passive subjectivity. Despite their relation they continue completely separated: the other requires cares and the I answers it the requests. The I-health professional answer becomes human because was affected by the otherness in the same time expresses the unknowable and supplicates for justice.
\end{abstract}

DESCRIPTORS: Humanization of assistance. Interpersonal relations. Ethics. Patient-centered care.

\section{HUMANIZAÇÃO DOS CUIDADOS EM SAÚDE: ENSAIO TEÓRICO REFLEXIVO FUNDAMENTADO NA FILOSOFIA DE EMMANUEL LÉVINAS}

RESUMO: O termo humanização tem sido frequente na área da saúde. Entretanto, não percebemos o apoio deste termo fundamentado em alguma teoria ou filosofia, dificultando a discussão da humanização em nível científico. O objetivo deste ensaio teórico é refletir sobre o termo humanização propondo um conceito fundamentado na filosofia de Emmanuel Lévinas. Propomos o conceito "relação eu-outro no e pelo ato de cuidar". A escolha da filosofia levinasiana para fundamentar tal conceito deve-se à finalidade das profissões da saúde e à complexidade que envolve o saber e o fazer destas profissões. Na relação eu-outro proposta por Lévinas, o outro apresenta-se como alteridade absoluta e o eu como subjetividade passiva. Apesar de estarem em relação, permanecem completamente separados: $o$ outro exige cuidados, o eu responde às suas solicitações. A resposta do eu profissional da saúde torna-se humana por ter sido afetado pela alteridade que, ao mesmo tempo, expressa o incognoscível e suplica justiça

DESCRITORES: Humanização da assistência. Relações interpessoais. Ética. Assistência centrada no paciente

\section{HUMANIZACIÓN DE LOS CUIDADOS EN SALUD: ENSAIO TEÓRICO REFLEXIVO FUNDAMENTADO EN LA FILOSOFÍA DE EMMANUEL LÉVINAS}

\begin{abstract}
RESUMEN: El término humanización ha sido frecuente en el área de la salud, sin embargo no se evidencia el apoyo a este término en alguna teoría/filosofía, dificultando la discusión a nivel científico. Objetivo: reflexionar sobre el término de humanización proponiendo un concepto basado en la filosofía de Emmanuel Lévinas. Proponemos el concepto "relación yo-otro" y "por el acto de cuidar". La elección de la filosofía levinasiana se debe a la finalidad de las profesiones de la salud y a la complejidad que involucra el saber y el hacer de estas profesiones. En la relación yo-otro propuesta por Lévinas, el otro se presenta como alteridad absoluta, el yo como subjetividad pasiva. Se relacionan y permanecen separados: el otro exige cuidados, el yo responde a las solicitudes. La respuesta del profesional de la salud se torna humana por haber sido afectado por la alteridad que, al mismo tiempo, expresa lo incognoscible y suplica justicia. DESCRIPTORES: Humanización de la atención. Relaciones interpersonales. Ética. Atención centrada en el paciente.
\end{abstract}




\section{INTRODUCTION}

The term humanization has been frequently used in the area of health. However, we do not perceive the term's support in a concept based in a theory or philosophy, which hinders the discussion of the issue of humanization at a scientific level.

The fact that the term humanization is polysemic $^{1}$ can hinder communication and even the expression of the humanization in the care practices.

Historically, the description of the set of factors which allows humanization or the de-humanization of healthcare has been present since the 1950s. ${ }^{2}$ The first efforts to conceptualize these terms date from the decade of the 1970s, and are a contribution from North American medical sociology. ${ }^{3}$

It was a North American sociologist who published the first work with the aim of conceptualizing the terms 'humanization' and 'dehumanization'. She reports that the first approach to these terms was based in the premise that human beings have biological and physiological needs. ${ }^{4}$ The attitudes guided to satisfy these should, therefore, be considered humanized. She adds that recognizing only the biological and physiological needs is insufficient to reach the human being completely. She proposes including the psychological needs, which cover expression and respect for one's self, affection, sympathy, and social relationships. For this author, humanizing the care would probably be to completely meet the needs of a human being, which presupposes that it is possible to access the human being completely. With this, the above-mentioned sociologist adds that it becomes difficult to assess the presence or absence of the dehumanization of the care, as the values are individual and cultural. ${ }^{4}$ In spite of this, she emphasizes that any context of care involves a minimum of two persons. This being the case, it is the live intersubjectivity of when the care is provided which effects a relational space. ${ }^{5}$

The word humanization has been used in situations in which, besides valorizing the care in its technical and scientific dimensions, the patient's rights are recognized ${ }^{*}{ }^{6}$ her individuality ${ }_{,}^{7}$ dignity, ${ }^{6}$ autonomy and subjectivity, ${ }^{8}$ are respected, without forgetting the recognition of the professional too as a human being, which presupposes a subject-subject relationship. ${ }^{2}$
In these works, the authors' concern with affirming the patients' citizenship becomes evident, along with, at the same time, the respect for their idiosyncrasies - that is, the harmony of the individual and collective rights of the subjects in a relationship of care. We emphasize that the above-mentioned authors used the terms 'patient' and 'professional', which refer to social roles, but also make use of terms which relate to a unique subject, such as individuality, autonomy and subjectivity.

In spite of this apparent indifferentiation between the two types of subjects, it seems to be consensual among the above-mentioned authors that, even when the subject is humanization, the central issue is the relationship between the health professional and the patient, characterizing the assistance which is personalized as humanized. We emphasize that here, an aporia occurs: at the same time as the authors refer to persons involved in the care through social roles (health professionals and patients), which to a greater or lesser extent entails stereotypes, they characterize the humanized relationship as devoid of social roles, that is, personalized.

The social roles appear based on customary systems, which allows members of the society to undertake certain acts automatically, allowing them to concentrate on new projects and ideas. On the other hand, the role has the degradation of the social relationships as its own structure, as, in undertaking the actions relevant to the roles taken on, the human beings do not need to show themselves as subjects, which hinders the knowledge about themselves and about the others and, at the same time, strengthens the behaviors necessary for the roles. ${ }^{9}$

The differentiation between individual subject and social subject becomes necessary in the relationship established between the subjects involved in the active caring, as the indifferentiation can lead to a relationship in which the social role is highlighted and the person who is cared for can be reduced to an object, that is, a relationship in which the professional finds herself with the subject without there being established, in this meeting, a person-to-person relationship. In establishing automatic behaviors based prioritarily in the social roles, the relationships of the time

* The person who receives the care shall be called patient, client, ill person or service user, according to the option of the author who is being cited. When the text is of the researcher, the term 'person' or 'other' shall be used. 
when care is provided are degraded, hindering the subjects' expression, which is essential for humanized care.

It is important to emphasize that both the health professional and the person who seeks the health service are persons who take on social roles when they interact in the healthcare context: both, as unique human beings. The fundamental difference between them is the singularity. At the level of the social role, the difference between these two people is produced in the fact that one, in that moment, needs care - and the other makes available her professional and human knowledges and skills in order to meet the demand made by the first.

In the Brazilian public health policy plan, the Ministry of Health implanted, in the year 2000, the National Program of Humanization of Hospital Care ${ }^{10}$ which defines humanization as the increase of the degree of co-responsibilization in the production of health and of subjects. In 2004, the Ministry of Health instituted the National Humanization Policy, ${ }^{11}$ extending humanization's reach. This document emphasizes the importance of including the principles of this policy, both in the training of professionals and in the management and organization of health work, its principles being based in the "values of the subjects' autonomy and protagonism, of co-responsibility between them, of solidarity of the bonds established, of the service users' rights, and of collective participation in the management process". ${ }^{12: 62}$

The works cited above presented ways of expressing humanization in the care practice. They emphasize the relational character and the singularity of the subjects who work there.

Following this brief presentation, we highlight some points: polysemy of the term 'humanization'; the inter-human question; and the character of the singularity of the subjects involved in the process of caring, who seem to accompany this term, even evidencing the paradox of treating singular questions with terms which relate to social roles. In the light of this, this theoretical reflexive essay aims to reflect on the term 'humanization' in the area of health, proposing a concept based in the thinking of Emmanuel Lévinas.

For this, the text which follows was organized in the following way: presentation of the concept of humanization which we propose, and its philosophical basis; the rationale for the choice of the philosophical framework, and exposure of the I-other relationship in levinassian philosophy.
HUMANIZATION IN THE AREA OF HEALTH: A THEORETICAL-REFLEXIVE CONCEPTUAL PROPOSAL

The theoretical reflection, in this essay, is based in the concept of "the I-other relationship in and through the act of caring", which is based in the philosophy of Emmanuel Lévinas.

Is it really essential to use different terms for the persons involved in the process of caring (I-other) if both are persons? We believe that this differentiation evidences the other as absolute alterity, differently from the expression "meeting of subjectivities". ${ }^{13}$

While "meeting of subjectivities" allows the objectification of the subject who shall be cared for, the "I-other relationship in and through the act of caring" impedes it through explaining the other as alterity.

The fact that in the "meeting of subjectivities" both the subjects are identified as subjectivities places them on the same plane: symmetry and reciprocity. This entails that the I can take responsibility for the other, besides dominating it. The "I-other relationship in and through the act of caring" makes the essential asymmetry of the relationship between the I and the other ("I-other relationship"). In this way, the concept proposed presents the other as an absolute alterity, as that which does not yield to objectification and, at the same time, demands its responsibility, allowing I and the other to relate while remaining separate.

\section{THE CHOICE OF THE PHILOSOPHY OF EMMANUEL LÉVINAS AS A BASIS FOR CONCEPT OF HUMANIZATION FOR THE HEALTH AREA}

This choice was suggested, fundamentally, by the purpose of the health professions and by the complexity which surrounds these professions' knowing and doing.

It is worth noting that Lévinas uses terms such as 'human' and 'humanization' in his works, but does not refer to the context of the care. It is dedicated to the relationship between an I and another which are concrete and, therefore, unique. As the term 'humanization' is used in the relational context, especially when this relationship has as a characteristic treating the other as a unique being, levinassian philosophy can be an option for basing the term 'humanization', even though the philosopher himself does not use it. 
In a general way, the health professions aimed to care for the other in varying contexts. We emphasize that this care is presented in a concrete relational field, effecting a relationship. If we consider both the subject and the relationship (I health professional, and the other) as subjectivities, we have to consider that, in a certain sense, they are identical: both are persons. This deduction is correct in one sense: person as a concept, which means universal, skillful, competent, moral, physical and legal beings . ${ }^{14}$ The conceptual claim is not a real plane, but as the plane of thought, of representations, of universals. There are no singularities in this plane, there are no concrete persons, we are at the level of the logos and "the logos is not sufficient to drive away ignominy". 15:29

In referring to a specific health professional (a concrete I, and not simply to a social role) and to a specific subject who requests care, the concept loses its priority, as the presentation of the other, as alterity, requires that this I responds to its demands and not those of a conceptual entity.

Therefore, the subjects involved in the process of caring, as persons, are, on the conceptual plane, identical; and on the real plane, are completely distinct. Here, the central dichotomy of the health professions is revealed, as caring for the health of the person considering the human question entails articulating the universal and the singular, subjecting the first to the second.

Irrespective of the degree to which caring for a person reflects on personalized care, in practice, these relationships are not always presented jointly. Caring for an illness is different from caring for an ill person, although these two ways are practiced by the health professionals.

Regardless of the type of care provided, the health professions present a body of scientific knowledge directed towards a specific professional practice, in which the I health professional faces the alterity.

Emmanuel Lévinas conceives of the alterity in an irreducible manner, an alterity which remains alterity, even when we relate with it. This is possible because the I-other relationship, described by Lévinas, is an asymmetric relationship. In this, the I can take responsibility for the other without asking for the same thing. Even though this reciprocity can entail a certain possession of the you, as in order to charge it regarding that which it can offer to the I, this would need to grasp it in some way (the I would need to know what the other can offer it, in order to make requests of it), which implies that the alterity would lose its absolute character.
Lévinas, differing from the ontological thinking which is based in the universals for responding to the singular, conceives of ethics as "primary philosophy", anterior to ontology (knowledge). Plus, Lévinas presents an alternative to Western philosophy which is immersed in ontology: the ethics of responsibility. Responsibility which is not chosen by the I, but which has always been a response to the request of the other. Thus, liberty is subordinated to responsibility, is finite because it is concrete, situated, the liberty of an I before another: the appeal of Lévinas "is not properly the exterior revolution, (...) Not because it does not see the need to change, but rather because it does not see the solution as reachable through external change, but only through internal change" ${ }^{\prime 16: 109}$

Having an ethics of the other before the I - the humanism which comes from the other man - the human relationship as proposed by Lévinas privileges the alterity of the neighbor, which often does not occur in the area of health and is of fundamental importance, when the aim of the service is to care for a concrete other, and not of the human genus. That is to say, to conceive of the other as alterity, we cannot follow the path which seeks the being (universal) in the other (singular). In this way, the alterity would be relative. We also cannot follow the path in which the I health professional is infinitely free. We need to seek a path in which the other imposes himself as alterity and thus truly remains in relating with the I. Conceiving of an alterity with this imposition seems to be a necessary component for supporting the relationships established between an I health professional and another, such that they relate while remaining singularities.

We could ask questions about the possibility and legitimacy of speaking of something which happens prior to knowledge (the I-other relationship) and, especially, in including such knowledges in the knowledges of the health professions. Lévinas starts from the relationship of an I with another to trace back to the origin beyond the logic. He makes use of the discourse to express this relationship, but this does not reduce to schemas, neither can it be encompassed by the concepts, as Lévinas uses concepts, and speaks and writes through them, "expresses itself with philosophical language. However, his true thinking is presented as coming from another world", 17:13 that of "other way of being", the world in which there is Other and which is the basis of the ontology. In order to express this face to face, which is how everything 
that is said of it is refuted, Lévinas makes use of a metaphorical language, as the metaphor refers to the absence: "an excellence identifying a totally different order of pure receptivity" ${ }^{18: 21}$ With this language, and with the ambiguity present in the face of the Other, ambiguity of the being and of the entity - the face appears as a silhouette and as the absolute other - it becomes possible to speak of a trace of alterity without our having it.

Health professionals are trained to direct themselves to the other with intentions - what are the signs and symptoms? - knowledges which are clearly ontological and, therefore, are based on an I which is free before being responsible, on an I health professional who is sovereign and, as such, takes responsibility for the other according to her wish and decision, that I which says that it knows what is better or worse for the other, which asserts whenever the other has or ceases to have autonomy (what sort of autonomy is that?). It is not an I health professional who lives for the other, but is an I which lives for itself, to meet its thirst to know and care. Levinassian philosophy does not belittle ontological knowledge, but repositions it, allowing us to look to the relationship between a caregiver and that person cared for, in such a way that the alterity prevails, or rather, in such a way that the alterity imposes, affecting the I.

In presenting itself as face, the other resists any thematization, is untouchable and indomitable and, thus, appears as fragile and with an essential need (lack of concept, if we wish) and, at the same time, with an imperative that demands responsibility from the I health professional, a responsibility which he did not choose, but which was entrusted to him. As a result, any action of the I health professional is already in response to the appeal which comes from the face, as to be I is to be passivity, it is to be to the other unconditionally and infinitely.

With this subjectivity which uncovers the human meaning of its existence in the embracing of the Other, we can conceive of a humanization of the care which does not subject itself to rules, but which forms the basis for the care and which, also, allows and gives meaning to the scientific and technical knowledges and to the public policies.

Thus, the health professionals deal with distinct dimensions in their practice: that of ontology, a dimension which knows and takes possession of the other (to know a pathology, the treatment, for example), and that of the alterity, which will never be understood due to being beyond the limits of comprehension of an I health professional. In spite of being distinct, these dimensions are articulatable, so long as the liberty of the I is concrete, that is to say, is situated in the responsibility for the other, which precedes it.

\section{I-OTHER}

We could ask: "who is the I? Who is the other?". The levinassian response falls back on the I-other relationship: the identity of the I appears from the face-to-face relationship; the other presents itself as I as face. In summary, the categories which exist, or can exist in the interpersonal relationships (autonomy, liberty, justice, responsibility, for example), emerge in the I-other relationship.

The starting point is the relationship of the I with the other, in which is the other is presented as a face, suggesting the idea of the infinite in the I, awakening this to an insatiable desire, evidencing the asymmetry between the I and the other, and placing the liberty of the I in question, and demanding responsibility from him.

This previous relationship of the I with the other already is language, the first discourse, ethical discourse. Language is not simply the way of placing the world in words, neither of knowing the other, it is a way of "expression of the thinking, (...) The condition of an attempt at communication" . ${ }^{99: 21}$ It is the way that the I health professional and the other meet, the other remaining alterity and the I "discovering itself" to be responsible. The ethical language has the meaning of respecting the alterity and making it impossible for the I to remain indifferent, faced with the Other. In this meeting, dialogue is produced, "the meeting is not union, but closening - (...) - of two discourses, mixing, avoiding each other: dia-logues" ${ }^{19: 22}$

In the levinassian philosophy, there are two discourses in the language. First: ethical discourse (saying), that in which the other is face, which is presented in its exteriority with the commandment "thou shalt not kill", an appeal of the other in the face of the powers of objectification of the I health professional. In this language in which the other is height and transcendence, it appears with the exteriority of a Master himself. The first teaching that the I health professional has in front of him relates to the limits of its powers, teaching which does not leave this I indifferent to the other, but, on the contrary, leads it to renounce its egoist world and offer it to the Other.

If, in the world, only an I and another existed, the I would take responsibility infinitely for 
the other, and, in principle, there would be no big conflicts. However, in this world there exist the I, the other and the others, who also demand responsibility of the I health professional and, in this context, the question arises: to whom should one respond first? With the entrance of the third party, the I has to ask itself about questions of priority, has to compare and judge,"15 "The other and the third party, my neighbors, contempories of one another, put distance between me and the other and the third party". ${ }^{20: 245}$

This distancing happens because the I neither remains indifferent to the entrance of the third party, nor expresses her love for the other. The entrance of the third party demands the thematization: "behind the unique singularities, it is necessary to have a glimpse of individuals of the genus, it is necessary to compare them, judge them and condemn them. (...). This is the hour of the inevitable justice which charity itself nevertheless demands". 21:241

It is the responsibility for the other and for the others which demands the movement of the I health professional from the transcendence of the sensitivity to the objectivity and universality. In other words, it is based on this first discourse (saying) that the second is possible, that the exchanging of information (said), by the fact of the third party appearing in the face: "Language as an exchange of ideas about the world, with the mental reservations it involves (...) presupposes the originality of the face". ${ }^{22: 176}$

It is important to clarify that the entrance of the third party is not always an empirical fact, it enters jointly with the other. In the face to face relationship, the third party appears in the face of the other: "The third party looks at me in the eyes of the Other. (...) The face in its nakedness as a face presents to me the destitution of the poor one and the stranger; but this poverty and exile which appeal to my powers, address me, do not deliver themselves over to these powers as givens, remain the expression of the face". 22:188

The Other, which is care by the I health professional, is presented in the discourse prior to the words, it is not possible to understand it, it expresses itself, it is face: "The way in which the other presents himself, exceeding the idea of the other in me, we here name face. (...) The face of the Other at each moment destroys and overflows the plastic image it leaves me, the idea existing to my own measure and to the measure of its ideatum the adequate idea. It does not manifest itself by these qualities, (...). It expresses itself". 22:21
We say that the face manifests itself in the sensitive (saying), that expresses itself because it is pure expression. It is an absolutely peculiar way of being, its way of expressing itself is transcendent, it cannot be shape or content, expresses itself in its nakedness, which means that it presents itself with absence of forms. Hence, it does not offer itself to science, to our powers, to our perceptions, it is not a content determined by the cultural horizon, which is concrete and relative. ${ }^{23}$ It is a content which transcends the knowing of an $\mathrm{I}^{22}$ and does not fit in any knowledge. The face clears itself from its own image and from any cultural ornament, ${ }^{18}$ is pure sensitivity or "an excessive reality", 15:116 "pure experience, experience without concept" ${ }^{\prime 24: 177}$

What happens for the face to resist objectification? The face expresses a reality which goes beyond the phenomenon in which the face is unveiled: "in the face, one finds a trace of something which passes by it and which is manifested in it", 17:119 the trace of the infinite, which impedes any objectification of the face.

The infinite, the idea of the infinite, is not an immense object which goes beyond the horizons of the gaze; it appears in the consciousness of the I health professional when this faces the other which is alterity. It is an idea which goes beyond its own idea, which goes beyond the capacity to think, which is empty in its appearance, and is an idea of the idea: "in thinking about the infinite - the I immediately thinks more than it thinks". 24:172 The I which thinks it establishes a relationship with the infinite, but it is a relationship which is different from that which exists between a thinking being and specified content, it is our relationship in another dimension, on another plane, the plane of the absolutely other, of the radically other, of transcendence, of the separate, and of the diachronic, that in which the time of the I health professional is not confused with the time of the transcendent. No matter how much the idea of the infinite is an idea, it is not a concept: "The infinite, against which every definition stands out, is not defined, (...), but also he signals himself by attending the work that signals him; he does not only signal himself, but speaks, is a face". $22: 72$

It is the only idea which teaches that which it discounts, ${ }^{24}$ as, as it is the only idea which is transcendent in relation to the I, it is the only which can bring content which is exterior to the I and, thus, possible to be known by it. However, it is a knowledge which is different from that which the I can grasp in the sense of dominating, it is a 
knowledge which teaches humanity to the I. The idea of the infinite is the first teaching: "The first teaching teaches this very height, tantamount to its exteriority, the ethical". .2:146 The idea of the infinite does not teach what it is, but without the other which is in front of the I is absolutely transcendent to it. This teaching, which comes from the Other, is knowledge, is the expression of the other. It is through the teaching that the person cared for presents her world to the I health professional, expresses the way she prefers to be cared for, her wishes and dreams.

The idea of the infinite is the infinite desire for the other, is produced as desire. ${ }^{24}$ The desire desires what is beyond everything which could complete it, it is the desire of the absolutely other. The desire respects the separation, different from the need: "Besides the hunger one satisfies, the thirst one quenches, and the senses one allays, metaphysics desires the Other beyond the representations, (...) A desire without satisfaction which, precisely, understands the remoteness, the alterity and the exteriority of the Other". 22:4

We think it is important to emphasize that it is the desire which understands the alterity and which, although in the I health professional, is awoken by the other in the movement of the care, not by the other as a simply sensitive being which can be grasped, but in that which he has which is the most unique, his alterity. This singularity which makes impossible any thematization is owed to the trace of the infinite that is expressed in the face. Hence, "the idea of the infinite is Desire". 17:27

This desire that the other, instead of satisfying, rouses, is a completely selfless desire (goodness). The desire and the goodness suppose a relationship in which the other holds all the powers of the I and this, before him, with no power, has only one duty: to respond to it, to take responsibility for it, to offer it the world which it possesses: "no face can be approached with empty hands and closed home: (...) hospitality is the concrete and initial fact of human recollection and separation". 22:147

The face only offers itself to the powers of the I in another sense in which it can be dead, that is, the I health professional can kill it as alterity, conceptualizing it, representing it. Because of this, "its logos [the logos of the face] is: 'Thou shalt not kill" "24:173 - "do not conceptualize me, do not objectify me" -, which means "do everything such that the other lives" 25:41 _ "offer me your knowledges".

This teaching which comes from the Other, appears in the sensitivity of the face, in the con- crete meeting of the I health professional with another, in which the face paralyzes the powers of the I through its ethical resistance: "resistance which does not have resistance", 22:173 through not placing limits on the liberty of the I, apart from placing it in question, through demanding that it adjusts itself: "the liberty of the I is not spontaneity, it is response to the Other which, not limiting the liberty of the I, calls it to the responsibility, which installs and justifies the liberty. It is the responsibility for the Other that leads the I to act (...). The I acts not for originally being free, but for being responsible". ${ }^{23: 85}$

The I health professional is not a free subject, and cannot use his knowledges in the way that he wishes, but is subject to the other, to her commandment; the I is "responsibility for everything and for all". ${ }^{15: 82}$ In this plane of responsibility is produced subjectivity and the alterity, due to the asymmetry which there is, between the I and the other. This does not mean that the I can choose nothing, but that its options are circumscribed in the relationship itself with Other. The I can choose the way of attending the other, as well as experiencing or not its responsibility.

In the asymmetry of the relationship of the I health professional with the other, this appears as height, as face, the Master of this I, and this appears as responsible for the other. This responsibility is the fundamental characteristic of the subjectivity, it is the identity itself of the I: "I am not, without responsibility". ${ }^{21: 37}$

The identity of the I health professional, in spite of coming from its interior, is not based upon it, on its autonomy, it originates in the presence of the other. ${ }^{23}$ The other is that which calls the I to its responsibility: "the identity of the I is not the result of any knowledge: I find myself without looking for myself". 19:87

In asserting that the process of individuation comes from responsibility, Lévinas achieves the subjectivity, not based on the universal, but on its singularity and concreteness, ${ }^{23}$ as it is only possible to take responsibility for somebody, and this somebody is another, which is presented in the face-to-face, affecting the I.

Thus, the responsibility does not arise from an obligation which begins from the I health professional, and is not one of its qualities. To be responsible for the other who addresses the I health professional is "one against my will which is more than I-same: it is an election. (...) nobody else can do that which he alone must do". 26:216 The fact of 
being chosen by Other shows that its responsibility is not a commitment taken on freely by the I health professional: "the elected belongs to the order of responsibility, (...) it is not found in a position of deciding what it wants to be in this respect" ${ }^{\prime 15: 82}$ This election explains two questions: the unique character of the subjectivity and that of situating the liberty of the I in its responsibility.

"Only the election becomes unique." 15:111 In its responsibility for the Other the I is insubstitutable. Only this unique I health professional can respond to that other which chose it. And, as we are talking of an I in its concreteness its way of responding is singular; "I as unicity, beyond all comparison, already on the edge of the community, of genus and form, (...), the difference with respect to itself - is the non-indifference ${ }^{\prime \prime}{ }^{20: 21}$

The Other is free, and chooses the I to respond to its call. The I health professional does not choose its responsibility for the other, this is prior to its liberty. The fact of the I responding, without a previous commitment, does not mean that its response has less merit than that of an I which chooses to take on this commitment, as a responsibility which is not taken on becomes infinite and undeclinable, which is the human fraternity prior to the liberty: "Responsibility for the Other, this way of answering without a prior commitment, is human fraternity itself, and it is prior to freedom". ${ }^{20: 184}$

It is important to clarify that even the responsibility of the I being evoked by the Other in the sensitivity of the face to face, this I health professional is not the slave of the other: "is not an abdication of the same, now alienated and slave to the other, but an abnegation of oneself fully responsible for the other". 20:111 The law which appears in the face destroys the definitive character of the I health professional and reveals "the path of obligations that introduce the human in being". 15:78 As it is through serving Other that the I health professional is constituted as an I human and not as a social role, we can assert that its vocation is the responsibility for Other, which "is not an accident that happens to a Subject, (...), has not awaited freedom, in which a commitment to another would have been made. (...). The ipseity, in the passivity without arché characteristic of identity, is a hostage. The word I means here I am, answering for everything and everyone". ${ }^{20: 180-1}$

How can the I be the hostage of the other? The condition of hostage is that in which somebody is, not through their own choice, in the power of Other as a guarantee that something shall be complied with. We would risk saying that the I health professional, before the other, becomes a hostage of the guarantee not to treat it as an object. Only an absolutely other would be capable of affecting the I to the point of paralyzing its powers in calling it to the undeclinable responsibility.

\section{FINAL CONSIDERATIONS}

We believe that the concept "I-other relationship in and through the act of caring" evidences the other, as austerity, and the absolute separation of the subjects (I-other) involved in the relationship, especially because we base this concept in the philosophy of Emmanuel Lévinas, in which the other is face. It imposes itself, destroying its plastic idea; and, at the same time, it asserts its alterity demanding responsibility of the I.

The Other is absolute alterity and the I, responsible for serving it, responsibility not derived from the professional Codes of Ethics, but which appears in the sensitivity of the face to face, and which can be a basis for it. This relationship, in which the I desires the undesirable and which discovers itself to be responsible at the same time in which it realizes its humanity, opens a space for the goodness and solidarity in an absolute way.

Levinassian philosophy requires that we think about the situation of care differently from the usual: the I health professional "is transformed" into a passive subject, the other is that which initiates the discourse ("thou shalt not kill") and the liberty of the I is finite (contingent), but this does not mean that Lévinas describes a utopian I-other relationship. It awakens in us the meeting with Other which happens in the sensitivity and which antecedes and makes possible the appearance of the ontology. To conceive of Other as completely exterior to the I health professional, affects it in such a way that it requires specific directing of the ontology, demands that the technical and scientific knowledges of the professional be submitted to the demands of the other, demands that the public policies always have the purpose of serving Other justly, attributing a character of singularity to the concept.

It is the fact that the "I-other relationship in and through the act of caring" leads to the categories which underlie the human relationships at a point previous to the attribution of values, we could dare to assert, that makes this concept universal. 
The proposal of this concept, based in the philosophy of Emmanuel Lévinas, makes it possible to address the issue of the humanization scientifically (concept and justification) and to invite, in particular, the health professionals to reflect on their practices.

\section{REFERENCES}

1. Heckert ALC, Passos E, Barros MEB. Um seminário dispositivo: a humanização do Sistema Único de Saúde (SUS) em debate. Interf Comunic Saúde Educ. 2009; 3(Supl 1):493-502.

2. Casate JC, Corrêa AK. Humanização do atendimento em saúde: conhecimento veiculado na literatura brasileira de enfermagem. Rev Latino-Am Enfermagem. 2005 Jan-Fev; 13(1):105-11.

3. Deslandes SF. Humanização: revisitando o conceito a partir das contribuições as sociologia médica. In: Deslandes SF, organizadora. Humanização dos cuidados em saúde: conceitos, dilemas e práticas. Rio de Janeiro (RJ): Fiocruz; 2006. p.33-47.

4. Howard J. Humanization and dehumanization of health care: a concept view. In: Howard J, Strauss A, editores. Humanizing health care. New York (US): John Wiley \& Sons; 1975. p.57-102.

5. Anéas TV, Ayres JRCM. Significados e sentidos das práticas de saúde: a ontologia fundamental e a reconstrução do cuidado em saúde. Interf. 2011 Jul-Set; 15(38):651-62.

6. Silva RCL, Porto IS, Figueiredo NMA. Reflexões acerca da assistência de enfermagem e o discurso de humanização em terapia intensiva. Esc Anna Nery Enferm. 2008 Mar; 12(1):156-9.

7. Teixeira GG, Chanes M. As estratégias de humanização da assistência ao parto utilizadas por hospitais ganhadores do prêmio galba de araújo: ações de mérito, ações premiadas. Mundo Saúde. 2003 Abr-Jun; 27(2):270-3.

8. Malheiros PA, Alves VH, Rangel TSA, Vargens OMC. Parto e nascimento: saberes e práticas humanizadas. Texto Contexto Enferm [online]. 2012 Abr-Jun; 21(2):329-37. [Acesso 2013 Jan 10]. Disponível em: http://www.scielo.br/scielo.php?script=sci arttext\&pid=S0104-07072012000200010 \&lng=pt\&nrm=iso

9. Heller A. Sobre os papéis sociais. In: Heller A. O cotidiano e a história. $8^{\mathrm{a}}$ ed. São Paulo (SP): Paz e Terra; 2008. p.115-43.
10. Ministério da Saúde (BR). Secretaria de Atenção à Saúde. Programa Nacional da Assistência Hospitalar. Brasília (DF): MS; 2000.

11. Ministério da Saúde (BR). Secretaria de Atenção à Saúde. Política Nacional de Humanização - a humanização como eixo norteador das práticas de atenção e gestão em todas as instâncias do SUS. Brasília (DF); 2004.

12. Ministério da Saúde (BR). Secretaria de Atenção à Saúde. Humaniza SUS: Política Nacional de Humanização: documento base para gestores e trabalhadores do SUS. Brasília (DF); 2004.

13. Almeida DV, Chaves EC, Brito JHS. Humanização dos cuidados de saúde: uma interpretação a partir da filosofia de Emmanuel Lévinas. Rev Ref. 2009 Jul; 2(10):89-96.

14. Lalande A. Vocabulário técnico e crítico da filosofia. $3^{\text {a }}$ ed. São Paulo (SP): Martins Fontes; 1999.

15. Chalier C. Lévinas - a utopia do humano. Lisboa (PT): Instituto Piaget; 1996.

16. Rico H. A sociedade do outro homem. Rev Port Filosofia. 1991; 47(1):97-117.

17. Nunes EPL. O outro e o rosto - problemas da alteridade em Emmanuel Lévinas. Braga (PT): Publicações da Faculdade de Filosofia da UCP; 1993.

18. Lévinas E. Humanisme de l’autre homme. Montpellier (FR): Fata Morgana; 1972.

19. Poirié F. Emmanuel Lévinas: ensaios e entrevistas. São Paulo (SP): Perspectiva; 2007.

20. Lévinas E. Autrement qu'être ou au-delà de l'essence. $5^{\mathrm{a}}$ ed. Paris (FR): Kluwer Academic (Le Livre de Poche); 2006.

21. Lévinas E. Entre nous - essais sur le penser-à-l'autre. $4^{\mathrm{a}}$ ed. Paris (FR): Grasset Le Livre de Poche; 2007.

22. Lévinas E. Totalité et infini. $4^{\text {a }}$ ed. La Haye (FR): Martinus Nijhoff Publishers; 1980.

23. Brito JHS. De Atenas a Jerusalém: a subjetividade passiva em Lévinas. Lisboa (PT): Universidade Católica Editora; 2002.

24. Lévinas E. La philosophie et l'idée de I’infini. In: En découvrant l'existence avec Husserl et Heidegger. Paris (FR): Librairie philosophique J. VRIN; 1967. p.165-78.

25. Lévinas E. Transcendence et inteligibilité. Genebra (SW): Labor et Fides; 1984.

26. Lévinas E. Dieu, la mort et le temps. Paris (FR): Bernard Grasset; 1993. 